УДК 615.225.2.03:001.8]-047.44

DOI https://doi.org/10.11603/2312-0967.2020.3.11426

\title{
ПОРІВНЯЛЬНИЙ АНАЛІЗ СПОЖИВЧИХ ВЛАСТИВОСТЕЙ ВАЛСАРТАНВМІСНИХ ПРЕПАРАТІВ З ПОГЛЯДУ АСИМЕТРІЇ ІНФОРМАЦІї
}

\author{
Л. М. Унгурян, О. І. Бєляєва, О. В. Смірнова, Х. Ю. Волощук, Т. І. Бербат, \\ Т. М. Ямілова, О. А. Степанова
}

Одеський національний медичний університет, Одеса

lianau@ukr.net

\section{ІНФОРМАЦІЯ}

Надійшла до редакції / Received: 13.05.2020

Після доопрацювання / Revised: 17.07.2020

Прийнято до друку / Accepted: 18.07.2020

\section{Ключові слова:}

інструкція для медичного

застосування, артеріальна

гіпертензія;

комбінованиий

валсартанвмісниий препарат;

асиметрія інсоормації.

\begin{abstract}
АНОТАЦІЯ
Мета роботи. Порівняльний аналіз текстів інструкцій до медичного застосування (IM3) комбінованих валсартанвмісних препаратів (КВП) 3 погляду асиметрії інфрормації.

Матеріали і методи. Матеріали дослідження: дані Державного реєстру лікарських засобів України станом на 01.09.2019 р., зокрема 7 інструкцій для медичного застосування торгових марок (ТМ) КВП у фрормі таблеток по 80 мг. Як методи дослідження були використані контент-аналіз, порівняльний, логічний, контекстуальний та квалітативний аналізи.

Результати й обговорення. Встановлено, що проаналізовані ТМ КВП відрізняються за складом допоміжних речовин. У текстах досліджуваних IM3 виявлено розбіжності щодо термінів придатності, показань і протипоказань до застосування, взаємодії з іншими лікарськими засобами, особливостей застосування у період вагітності, під час годування груддю та у дітей, а також побічних реакцій ТМ КВП. Результатом цих комунікативних розбіжностей може стати нераціональне призначення ТМ КВП хворим на артеріальну гіпертензію внаслідок неадекватного сприйняття тексту IM3, що може привести до розвитку негативних реакцій.

Висновки. На підставі порівняльної оцінки споживчих властивостей 7 ТМ КВП у фрормі таблеток по 80 мг виявлено асиметричність інформації щодо їхньої фрармакологічної ідентичності унаслідок різночитань змісту тексту в більшості IM3. Зазначене вказує на те, що лікарі з метою забезпечення достовірного і безпечного призначення ТМ КВП повинні враховувати встановлені відмінності в їхніх споживчих властивостях та індивідуальному підході до призначення пацієнтам.
\end{abstract}

Вступ. На сьогодні вітчизняний фрармацевтичний ринок насичений відтвореними лікарськими засобами (Л3). В умовах широкого асортименту Л3, що містять один і то й же активний фрармацевтичний інгредієнт (АФІ), важливою є проблема взаємозаміни. Лікарям і фрармацевтичним працівникам необхідно враховувати, що ЛЗ із однією міжнародною непатентованою назвою (МНH), представлені в однаковій лі- карській фрормі, можуть володіти різними споживчими властивостями [1].

Офріційно затвердженою інфрормацією про медичне застосування ЛЗ, що супроводжує готовий ЛЗ, є інструкція для медичного застосування (IM3) [2]. Проте наявність на фрармацевтичному ринку України багатьох торгових марок (ТМ) одного й того ж ЛЗ за МНН може призвести до комунікативної розбіжності в текстах IM3 Л3 [3, 4].

ISSN 2312-0967. Pharmaceutical review. 2020. № 3 
Нині на фрармацевтичному ринку України для лікування артеріальної гіпертензії у пацієнтів, тиск крові яких належно не регулюється монотерапією, широко затребувана група комбінованих антагоністів ангіотензину II та діуретиків, одними з представників яких $€$ комбіновані валсартанвмісні препарати (КВП).

У 2018 р. Європейське агентство 3 ЛЗ (ЕМА) виявило у готових ЛЗ на основі АФІ валсартану, виробництва «Чжецзян Хуахай Фармасьютикал Ко. Лтд» (Китай), який постачав її фармацевтичним компаніям-виробникам по всьому світу, потенційно канцерогенну домішку N-нітрозодиметиламіну (NDMA). Власне в липні 2018 р. Державна служба України з ЛЗ та контролю за наркотиками почала проводити заходи 3 вилучення з обігу Л3, що виготовлені з використання АФІ валсартану зазначеного вище виробника [5].

Мета роботи - порівняльний аналіз текстів ІМЗ КВП із погляду асиметрії інформації.

Матеріали і методи. Матеріалами дослідження було обрано 7 текстів ІМЗ ТМ КВП у таблетках по 80 мг, внесених у Державний реєстр лЗ станом на 01.09.2019 р., серії яких не потрапили під заборону обігу, а саме: Вальсакор Н (КРКА д.д., Ново место, Словенія), Вазар Н (Актавіс ЛтД, Мальта; Балканфарма-Дупниця АТ, Болгарія), (Фармацевтичний завод «Польфарма» С. А., Польща), Корсар Н (ПАТ «Фармак», Україна), Сакорд Н (Балканорарма - Дупниця АД, Болгарія), Тіара Дуо (ПрАТ «Фармацевтична фрірма «Дарниця», Україна), Діокор 80 (ТОВ «Фарма Старт», Україна) [6]. Всі зазначені Л3 відпускаються за рецептом лікаря.

Вибір ІМЗ лз обґрунтований тим, що ії текст, з одного боку, виступає інструментом опосередкованої комунікації між лікарем і пацієнтом, з іншого - сприяє досягненню головної мети лікаря і фрармацевтичного працівника, що полягає в успішному інсрормуванні споживача щодо правильного приймання потрібного йому Л3. Аналіз текстів IMЗ КВП проведено за наступними споживчими характеристиками: склад, показання до застосування, протипоказання, взаємодія з іншими Л3, побічні ефекти, особливості застосування в період вагітності, під час годування груддю та в дітей.

Як методи дослідження були використані контентаналіз, порівняльний, логічний, контекстуальний та квалітативний аналізи.

Результати й обговорення. Встановлено, що серед аналізованих ТМ КВП лише для Вазар Н та Ванатекс Комбі взаємозамінність доведена шляхом проведення дослідження in vivo біоеквівалентності (B1) [7]. На думку дослідників [8], твердження щодо фармакологічної ідентичності Л3-аналогів різних ТМ без підкріплення даними про біоеквівалентність містять асиметричну інорормацію та можуть спричинити пов'язані з ліками проблеми.

Виявлено, що ТМ КВП різняться за назвою і кількістю допоміжних речовин (ДР). За даними таблиці 1, всього в досліджуваних ТМ використано 19 ДР від 8 до 14 в одному ЛЗ.

Найчастіше використовували магнію стеарат, кремнію діоксид колоїдний безводний, титану діоксид (E 171) і макрогол (усі ТМ); целюлозу мікрокристалічну, натрію кроскармелозу і заліза оксид червоний (Е 172) у 6 TM; лактозу моногідрат, полівініловий спирт і заліза оксид жовтий (Е 172) у 5 ТМ. Допоміжні речовини, які входять до складу ЛЗ, впливають на стабільність та термін їх придатності. Зокрема, за даними ІМЗ, термін придатності ТМ Тіара Дуо становить 2 роки, Ванатекс Комбі, Корсар Н, Сакорд Н і Діокор 80 - 3 роки, Вазар Н і Вальсакор $\mathrm{H}-4$ роки та 5 років відповідно.

Результати подальшого аналізу показали деякі розбіжності в показаннях ТМ КВП, а саме такими для чотирьох досліджуваних ТМ $є$ ессенціальна артеріальна гіпертензія (Вазар Н, Сакорд Н, Тіара Дуо, Діокор 80), а для трьох - артеріальна гіпертензія, тобто Вальсакор Н, Ванатекс Комбі та Корсар Н, на відміну від інших ТМ, може застосовуватися для фрармакотерапії вторинної гіпертензії (симптоматичної), частота якої не перевищує 10 \% всіх випадків АГ [9].

Далі досліджено специфріку протипоказань ТМ КВП. За даними таблиці 2, в усіх ІМ3 досліджуваних ЛЗ вказано загалом 8 протипоказаннь. При цьому 53 них є спільними, а саме: підвищена чутливість до АФІ та/або ДР, а також до похідних сульфонамідів; тяжкі порушення фрункції печінки, біліарний цироз печінки або холестаз; анурія, тяжкі порушення функції нирок (кліренс креатиніну < 30 мл/хв); рефрактерна гіпокаліємія, гіпонатріємія, гіперкальціємія, симптоматична гіперурикемія.

Встановлено, що в деяких текстах IMЗ ЛЗ відсутні відомості, що наявні в текстах інших ІМЗ ТМ КВП. Так, лише в ІМЗ Вазару Н вказано протипоказання щодо підвищеної чутливості до арахісу чи сої. Важливим протипоказанням у 6 ТМ КВП є одночасне застосування ЛЗ з аліскіреном. Тільки у Корсару Н це не вказано навіть у розділі при описі взаємодії з іншими ЛЗ.

У ході порівняльної оцінки взаємодії досліджуваних ТМ з іншими ЛЗ було встановлено, що в IMЗ вказані особливості одночасного застосування для АФІ як окремо, так і спільні рекомендації. Оскільки аналізовані ТМ є комбінованими, то тексти IM3 мають такі розділи:

- «Взаємодії, пов'язані як з валсартаном, так і з гідрохлоротіазидом», в якому до всіх ТМ КВП вказаний літій як не рекомендований до одночасного застосування. Також в усіх текстах IM3 можна зустріти попередження про обережність при одночасному застосуванні таких ЛЗ, як пресорні аміни, нестероїдні протизапальні препарати (НПЗ3), включно селективні інгібітори цОГ-2, ацетилсаліцилову кислоту > 3 г/ добу та неселективні НПЗЗ та інші антигіпертензивні препарати.

ISSN 2312-0967. Фармацевтичний часопис. 2020. № 3 
Таблиця 1

Перелік допоміжних речовин у торгових марках комбінованих варсалтанвмісних преператів

\begin{tabular}{|c|c|c|c|c|c|c|c|c|}
\hline \multirow[b]{2}{*}{ Склад ДР } & \multicolumn{7}{|c|}{ ТМ КВП } & \multirow[b]{2}{*}{ Разом } \\
\hline & $\begin{array}{c}\text { Валь- } \\
\text { сакор } \\
\text { H }\end{array}$ & $\begin{array}{c}\text { Вазар } \\
\mathrm{H}\end{array}$ & $\begin{array}{c}\text { Вана- } \\
\text { текс } \\
\text { Комбі }\end{array}$ & $\begin{array}{l}\text { Kop- } \\
\text { cap H }\end{array}$ & $\begin{array}{c}\text { Ca- } \\
\text { корд H }\end{array}$ & $\begin{array}{c}\text { Tiapa } \\
\text { Дуо }\end{array}$ & $\begin{array}{c}\text { Діокор } \\
80\end{array}$ & \\
\hline 1. Лактоза моногідрат & + & + & + & + & + & - & - & 5 \\
\hline 2. Ц Целюлоза мікрокристалічна & + & + & - & + & + & + & + & 6 \\
\hline 3. Магнію стеарат & + & + & + & + & + & + & + & 7 \\
\hline 4. Натрію кроскармелоза & + & + & + & + & + & - & + & 6 \\
\hline 5. Натрію лаурилсульсрат & - & - & - & - & - & - & + & 1 \\
\hline 6. Кремнію діоксид колоїдний безводний & + & + & + & + & + & + & + & 7 \\
\hline 7. Крохмаль кукурудзяний & - & - & - & - & - & - & + & 1 \\
\hline 8. Крохмаль картопляний & - & - & - & - & - & - & + & 1 \\
\hline 9. Гіпромелоза & + & - & + & - & - & - & - & 2 \\
\hline 10. Повідон & + & + & - & + & + & - & - & 4 \\
\hline 11. Кросповідон & - & - & - & - & - & + & - & 1 \\
\hline 12. Полівініловий спирт & - & + & - & + & + & + & + & 5 \\
\hline 13. Титану діоксид (Е 171) & + & + & + & + & + & + & + & 7 \\
\hline 14. Макрогол & + & + & + & + & + & + & + & 7 \\
\hline 15. Заліза оксид жовтий (Е 172) & + & + & - & + & + & + & - & 5 \\
\hline 16. Заліза оксид червоний (Е 172) & + & + & + & + & + & + & - & 6 \\
\hline 17. Заліза оксид чорний (Е 172) & - & - & - & + & + & - & - & 2 \\
\hline 18. Лецитин & - & + & - & + & + & + & - & 4 \\
\hline 19. Тальк & - & + & - & + & + & - & + & 4 \\
\hline Всього & 11 & 13 & 8 & 14 & 14 & 10 & 11 & 81 \\
\hline Термін придатності Л3, роки & 5 & 4 & 3 & 3 & 3 & 2 & 3 & $\mathrm{x}$ \\
\hline
\end{tabular}

\section{Таблиця 2}

Протипоказання торгових марок комбінованих варсалтанвмісних преператів

\begin{tabular}{|c|c|c|c|c|c|c|c|}
\hline \multirow[b]{2}{*}{ Показники } & \multicolumn{7}{|c|}{ ТМ КВП } \\
\hline & $\begin{array}{c}\text { Вальса- } \\
\text { кор Н }\end{array}$ & $\begin{array}{c}\text { Вазар } \\
\mathrm{H}\end{array}$ & $\begin{array}{l}\text { Вана- } \\
\text { текс } \\
\text { Комбі }\end{array}$ & $\begin{array}{l}\text { Kop- } \\
\text { cap H }\end{array}$ & $\begin{array}{c}\mathrm{Ca}- \\
\text { корд } \\
\mathrm{H}\end{array}$ & $\begin{array}{c}\text { Tiapa } \\
\text { Дуо }\end{array}$ & $\begin{array}{l}\text { Діокор } \\
80\end{array}$ \\
\hline \multicolumn{8}{|l|}{ Для всіх ТМ } \\
\hline \multicolumn{8}{|l|}{ 1. Підвищена чутливість до АФІ та/або ДР } \\
\hline \multicolumn{8}{|c|}{ 2. Тяжкі порушення фрункції печінки, біліарний цироз печінки або холестаз } \\
\hline \multicolumn{8}{|c|}{ 3. Анурія, тяжкі порушення фрункції нирок (кліренс креатиніну < 30 мл/хв) } \\
\hline \multicolumn{8}{|c|}{ 4. Рефрактерна гіпокаліємія, гіпонатріємія, гіперкальціємія, симптоматична гіперурикемія } \\
\hline \multicolumn{8}{|c|}{ 5. Підвищена чутливість до похідних сульсронамідів } \\
\hline 6. Вагітним та жінкам, які планують завагітніти & + & + & + & - & + & + & + \\
\hline 7. Підвищена чутливість до арахісу чи сої & - & + & - & - & - & - & - \\
\hline $\begin{array}{l}\text { 8. Супутнє застосування антагоністів рецепто- } \\
\text { рів ангіотензину (АРА), включно валсартан, або } \\
\text { інгібіторів ангіотензинперетворювального фрер- } \\
\text { мента (АПФ) } 3 \text { аліскіреном пацієнтам із цукровим } \\
\text { діабетом або з порушеннями функції нирок }\end{array}$ & + & + & + & - & + & + & + \\
\hline
\end{tabular}

ISSN 2312-0967. Pharmaceutical review. 2020. № 3 
- «Взаємодії, пов'язані з валсартаном», у якому для всіх IM3, які не рекомендовані до супутнього використання, зазначені Л3, що здатні підвищувати рівень калію в крові. Рекомендовано також для всіх ТМ, крім Корсар Н, проявляти необхідну обережність при одночасному застосуванні інгібіторів транспортера поглинання або транспортерів ефлюксу. Окремо у всіх IMЗ надається інорормація, що у дослідженнях лікарської взаємодії валсартану не встановлено клінічно значущої взаємодії валсартану та будь-якого з нижчезазначених лз: циметидин, варфарин, фуросемід, дигоксин, атенолол, індометацин, гідрохлоротіазид, амлодипін, глібенкламід.

- «Взаємодії, пов'язані з гідрохлоротіазидом» майже у всіх IM3 наведені переліки груп Л3, як такі, що вимагають обережності при одночасному застосуванні з ним, за винятком ТМ Корсар Н, Діокор 80 та Ванатекс Комбі. Слід також зазначити, що у ТМ Вазар $\mathrm{H}$, Сакорд $\mathrm{H}$, Тіара Дуо є застереження щодо обережності у супутньому застосуванні 3 Л3, здатними індукувати шлуночкову тахікардію типу «пірует», але захворювання вказується вже як двонаправлена тахікардія «torsades de pointes». У текстах IMЗ шести ТМ КВП інформується про подвійну блокаду ренін-ангіотензин-альдостеронової системи (РАAC) препаратами груп APA, ІАПФ або аліскіреном як те, що потребує обережності, нагляду лікаря або взагалі не рекомендується. Тільки в тексті ІМЗ до Корсару Н не зазначено про обережність одночасного використання л3, що впливають на рівень натрію у сироватці крові та про подвійну блокаду РААС на відміну від інших об'єктів дослідження.

При дослідженні особливостей застосування у період вагітності та під час годування груддю (табл. 3) з'ясовано, що для 5 ТМ КВП цей період є категоричним протипоказанням, для Вазар $\mathrm{H}$ «не застосовують в цей час», а для Тіара Дуо - «не слід застосовувати». При цьому для всіх ТМ КВП зазначається особлива умова застосування - якщо під час лікування ними підтверджується вагітність, його застосування необхідно негайно припинити і замінити іншим ЛЗ, дозволеним для застосування вагітним.

Щодо застосування під час годування груддю, то у тексті ІІМЗ вказано, що за необхідності лікування Вальсакором H, Корсаром $\mathrm{H}$, Сакордом $\mathrm{H}$, Тіарою Дуо та Діокором 80 слід припинити годування груддю, а при призначенні Вазару Н і Ванатекс Комбі годування груддю не рекомендується. У педіатрії, за даними ІМЗ, Діокор 80 не слід застосовувати, а решта ТМ - не рекомендується.

щодо передозування та побічних реакцій ТМ КВП, то основною ознакою передозування АФІ валсартаном може бути артеріальна гіпотензія з запамороченням. Лікування залежить від часу, що минув після приймання Л3, і тяжкості симптомів; стабілізація гемодинаміки є найбільш важливою.

На завершальному етапі дослідження встановлено, що при застосуванні всіх ТМ КВП можуть виникати побічні ефекти, найбільшу кількість яких має Діокор 80, найменшу - Ванатекс Комбі. За даними рисунка 1, тексти аналізованих IM3 містять в середньому 13 груп ПР при розмаху варіації від 11 до 14. При цьому кількість можливих несприятливих клінічних проявів складає в середньому 82 та знаходяться в межах від 22 до 107.

Узагальнюючи проведені дослідження, слід зазначити, що результати дослідження вказують на наявність асиметричності інформації в текстах IM3 7 ТМ КВП. Тому медичним та фрармацевтичним працівникам необхідно враховувати проблему комунікативної розбіжності IM3 Л3-аналогів із метою забезпечення достовірного і безпечного призначення і застосування ЛЗ пацієнтами. Відмінності в споживчих характеристиках ідентичних за складом ТМ КВП свідчать про наявність двох основних фракторів впливу: особливості технологічного процесу, який використовується промисловими підприємствами та різному кількісному вмісту допоміжних речовин.

Таблиця 3

Застосування ТМ КВП у період вагітності, під час годування груддю та в дітей

\begin{tabular}{|c|c|c|c|}
\hline \multirow{2}{*}{ ТМ КВП } & \multicolumn{3}{|c|}{ Особливості застосування } \\
\hline & у період вагітності & під час годування груддю & у дітей \\
\hline Вальсакор Н & протипоказано & $\begin{array}{l}\text { годування груддю слід } \\
\text { припинити }\end{array}$ & \multirow{6}{*}{ не рекомендується } \\
\hline Вазар H & не застосовувати & \multirow{2}{*}{$\begin{array}{l}\text { годування груддю не } \\
\text { рекомендується }\end{array}$} & \\
\hline Ванатекс Комбі & \multirow[t]{3}{*}{ протипоказано } & & \\
\hline Kopcap H & & \multirow{4}{*}{$\begin{array}{l}\text { годування груддю слід } \\
\text { припинити }\end{array}$} & \\
\hline Сакорд Н & & & \\
\hline Тіара Дуо & не слід застосовувати & & \\
\hline Діокор 80 & протипоказано & & не слід застосовуват \\
\hline
\end{tabular}

ISSN 2312-0967. Фармацевтичний часопис. 2020. № 3 


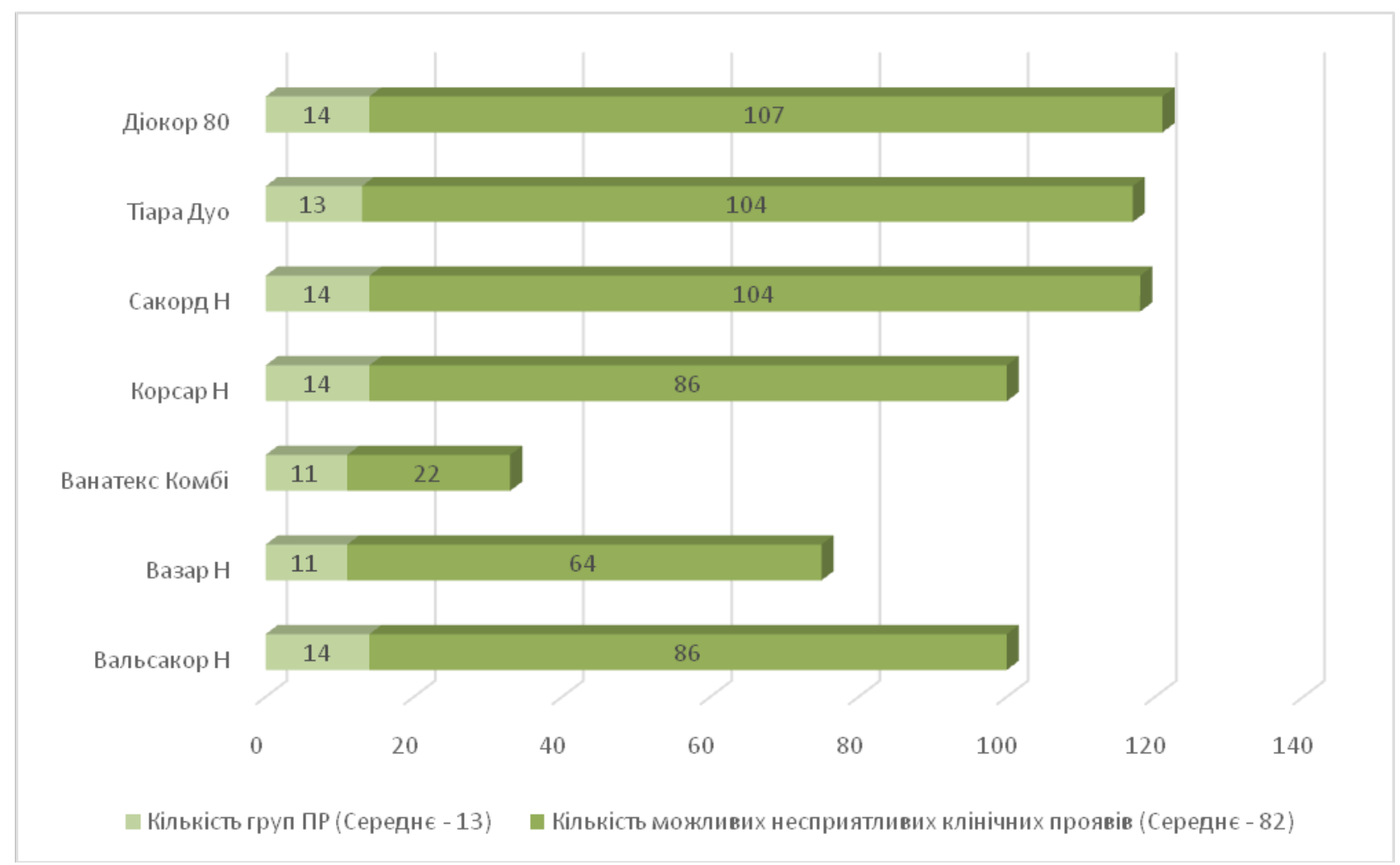

Рис. 1. Число ПР комбінованих ТМ Валсартану.

Висновки. На підставі порівняльної оцінки споживчих властивостей 7 ТМ КВП у фрормі таблеток по 80 мг виявлена асиметричність інфрормації щодо фрармакологічної ідентичності ТМ-аналогів унаслідок різночитань змісту тексту у більшості ІМЗ. Зазначене вказує на те, що лікарі з метою забезпечення достовірного і безпеч- ного призначення ТМ КВП повинні враховувати встановлені відмінності в їхніх споживчих властивостях та індивідуальному підході до призначення пацієнтам.

Конфлікт інтересів: відсутній.

Conflicts of interest: authors have no conflict of interest to declare.

\section{COMPARATIVE ANALYSIS OF CONSUMER PROPERTIES OF VALSARTAN-CONTAINING DRUGS IN TERMS OF ASYMMETRIC INFORMATION}

\section{M. Unhurian, O. I. Bielyaieva, O. V. Smirnova, H. Yu. Voloshchuk, T. I. Berbat, T. M. Yamilova, O. A. Stepanova}

\section{Odesa National Medical University \\ lianau@ukr.net}

The aim of the work. Comparative analysis of package inserts of combined valsartan-containing drugs in terms of asymmetric information.

Materials and Methods. Data of the State Register of Medicines of Ukraine as of September 1, 2019, in particular 7 package inserts of trademarks of Combined Valsartans. As research methods the content, comparative, logical, contextual and qualitative analysis were applied.

Results and Discussion. There is a discrepancy in some sections of the text contents of 7 trademarks of Combined Valsartans. The results confirmed the asymmetry of information about the pharmacological identity of drugs-analogues without prooving of bioequivalence data. Also, it shows the need to take into consideration the communicative differences in the package inserts of analogues to ensure safe prescribing of drugs and reduce drug problems due to their use.

Conclusions. The analysis allows us to conclude that the information in the package inserts provided by the manufacturers is not complete. In order to ensure the reliable and safe administration of the studied drugs, healthcare 
professionals should not forget about the established differences in their consumer properties and individual approach to use by patients.

Key words: package inserts; arterial hypertension; combined valsartan-containing drugs; asymmetric information.

\title{
СРАВНИТЕЛЬНЫЙ АНАЛИЗ ПОТРЕБИТЕЛЬСКИХ СВОЙСТВ ВАЛСАРТАНСОДЕРЖАЩИХ ПРЕПАРАТОВ С ТОЧКИ ЗРЕНИЯ АСИММЕТРИИ ИНФОРМАЦИИ
}

\author{
Л. М. Унгурян, О. И. Беляева, О. В. Смирнова, К. Ю. Волощук, Т. И. Бербат, Т. М. Ямилова, \\ О. А. Степанова
}

\author{
Одесский национальный медицинский университет \\ lianau@ukr.net
}

\begin{abstract}
Цель работы. Сравнительный анализ текстов инструкций к медицинскому применению (ИМП) комбинированных валсартансодержащих препаратов (КВП) с точки зрения асимметрии инорормации.

Материалы и методы. Материалы исследования: данные Государственного реестра лекарственных средств Украины по состоянию на 01.09.2019 г., в частности 7 ИМП торговых марок (ТМ) КВП в форме таблеток по 80 мг. В качестве методов исследования были использованы контент-анализ, сравнительный, логический, контекстуальный и квалитативный анализы.

Результаты и обсуждение. Выявлено, что проанализированные ТМ КВП отличаются по составу вспомогательных веществ. В текстах исследуемых ИМП выявлены различия по срокам годности, показаниям и противопоказаниям к применению, взаимодействиям с другими лекарственными средствами, особенностям применения в период беременности, во время кормления грудью и у детей, а также побочным реакциям ТМ КВП. Результатом этих коммуникативных разногласий может стать нерациональное назначение ТМ КВП больным с артериальной гипертензией вследствие неадекватного восприятия текста ИМП, что может привести к развитию негативных реакций.

Выводы. На основании сравнительной оценки потребительских свойств 7 ТМ КВП в фрорме таблеток по 80 мг обнаружена асимметрия информации о их фрармакологической идентичности вследствие разночтений содержания текста большинства ИМП. Установленное означает, что врачи с целью обеспечения достоверного и безопасного назначения ТМ КВП должны учитывать различия в их потребительских свойствах с целью индивидуального подхода к назначению пациентам.
\end{abstract}

Ключевые слова: инструкция по медицинскому применению; артериальная гипертензия; комбинированный валсартансодержащий препарат; асимметрия инсрормации.

\section{Список бібліографічних посилань}

1. Громовик Б. П., Парновський Б. Л., Унгурян Л. М. Реалії асиметрії інформації у фрармацевтичній опіці. Одеський медичний журнал. 2012. № 3. С. 30 - 33.

2. Про затвердження Порядку проведення експертизи реєстраційних матеріалів на лікарські засоби, що подаються на державну реєстрацію (перереєстрацію), а також експертизи матеріалів про внесення змін до реєстраційних матеріалів протягом дії реєстраційного посвідчення : Наказ MO3 України від 26. серп. 2005 р. № 426. URL: http:// zakon2.rada.gov.ua/ laws/show/z1069-05

3. Гадяк І. В., Громовик Б. П. Дослідження змісту офріційно затвердженої інформації про медичне застосування торгових марок тамсулозину. Управління, економіка та забезпечення якості в фрармації. 2018. № 1. С. 20-27.

4. Громовик Б. П., Матвійчук М. Є. Дослідження асиметрії інфрормації нормативних документів щодо лікарських засобів для фрармакотерапії депресивних розладів у вагітних і породіль.
Фармацевтичний часопис. 2019. № 3. С. 111-122. doi.org/10.11603/2312-0967.2019.3.10408

5. Заборона валсартану: Держлікслужба рекомендує виробникам провести аналіз зразків готової продукції. URL: https://www.apteka.ua/article/467032

6. Державний реєстр лікарських засобів України. URL : http://www.drlz.com.ua

7. Довідник еквівалентності лікарських засобів. URL: https://rx.ua/ru/inn-mnn/valsartan-gidrohlorotiazid.

8. Унгурян Л. М., Кресюн В. Й., Громовик Б. П. Зміст текстів інструкцій для медичного застосування препаратів-аналогів з погляду асиметрії інсрормації та пов'язаних із ліками проблем. Одеський медичний журнал. 2013. № 6. С. $27-32$.

9. Про затвердження та впровадження медикотехнологічних документів зі стандартизації медичної допомоги при артеріальній гіпертензії : наказ МО3 України від 24 трав. 2012 р. № 384. URL: http://www. apteka.ua/article/151151.

ISSN 2312-0967. Фармацевтичний часопис. 2020. № 3 


\section{References}

1. Hromovyk BP, Parnovskyi BL, Unhurian LM. [Realities of information asymmetry in pharmaceutical care]. Odeskyi medychnyi zhurnal. 2012;3: 30-3. Ukrainian.

2. On approval of the Procedure for examination of registration materials for medicinal products submitted for state registration (re-registration), as well as examination of materials on amendments to registration materials during the registration certificate: Order of the Ministry of Health of Ukraine dated August 26. 2005 No. 426. [Internet]. Available from: http://zakon2.rada.gov. ua/ laws/show/z1069-05

3. Hadiak IV, Hromovyk BP. [Study of the content of officially approved information on the medical use of trademarks tamsulosin]. Upravlinnia, ekonomika ta zabezpechennia yakosti $v$ farmatsii. 2018;1: 20-7. Ukrainian.

4. Hromovyk BP, Matviichuk Mle. [Study of information asymmetry of regulatory documents on drugs for pharmacotherapy of depressive disorders in pregnant women and women in labor]. Farmatsevtychnyi chasopys.
2019;3: 111-22. Ukrainian. DOI.org/10.11603/23120967.2019.3.10408.

5. Prohibition of valsartan: The State Medical Service recommends that manufacturers analyze samples of finished products [Internet]. Morion; 2018. Available from: https://www.apteka.ua/article/467032.

6. State Register of Medicines of Ukraine [Internet]. Available from: http://www.drlz.com.ua

7. Handbook of drug equivalence [Internet]. Available from: https://rx.ua/ru/inn-mnn/valsartan-gidrohlorotiazid.

8. Unhurian LM, Kresiun VY, Hromovyk BP. [Contents of the instructions for medical use of analogue drugs in terms of asymmetry of information and drug-related problems]. Odeskyi medychnyi zhurnal. 2013;6: 27-32. Ukrainian.

9. On approval and introduction of medical and technological documents on standardization of medical care at arterial hypertension: the Order of the Ministry of Health of Ukraine of May 24, 2012 No. 384 [Internet]. Available from: http://www.apteka.ua/article/151151.

\section{Відомості про авторів}

Унгурян Л. М. - Д. фрармац. наук, проф., завідувач кафедри організації та економіки фрармації, Одеський національний медичний університет, Одеса, Україна. E-mail: lianau@ukr.net, ORCID 0000-0001-5391-9676.

Бєляєва О. І. - канд. фрармац. наук, доцент, доцент кафедри організації та економіки фрармації, Одеський національний медичний університет, Одеса, Україна. E-mail: boioef@ukr.net, ORCID 0000-0001-6792-5911.

Смірнова О. В. - канд. фрармац. наук, ст. викладач кафедри організації та економіки фрармації, Одеський національний медичний університет, Одеса, Україна. E-mail: crocus_aesthetic@my.com, ORCID 0000-0001-8420-5617.

Волощук X. Ю. - асистент кафедри організації та економіки фрармації, Одеський національний медичний університет, Одеса, Україна. E-mail: volosh20@ukr.net, ORCID 0000-0002-9267-3573.

Бербат Т. І. - канд. хім. наук, асистент кафедри організації та економіки фрармації, Одеський національний медичний університет, Одеса, Україна. E-mail: berbat@ukr.net, ORCID 0000-0003-0788-5799.

Ямілова Т. М. - канд. мед. наук, доцент кафедри професійної патології та фрункціональної діагностики, Одеський національний медичний університет, Одеса, Україна. E-mail: juravuhk@gmail.com, ORCID 0000-0001-9609-1688.

Степанова О. А. - ст. викладач кафедри організації та економіки фармації, Одеський національний медичний університет, Одеса, Україна. E-mail: stepanova74@ukr.net, ORCID 0000-0003-3218-2702.

\section{Information about the authors}

Unhurian L. M. - DSc (Pharmacy), Professor, Head of the Organization and Economics of Pharmacy Department, Odesa National Medical University, Odesa, Ukraine. E-mail: lianau@ukr.net, ORCID 0000-0001-5391-9676.

Bielyaieva O. I. - PhD (Pharmacy), Associate Professor of the Department of Organization and Economics of Pharmacy, Odesa National Medical University, Odesa, Ukraine. E-mail: boioef@ukr.net, ORCID 0000-0001-6792-5911.

Smirnova O. V. - PhD (Pharmacy), Senior Lecturer of the Department of Organization and Economics of Pharmacy, Odesa National Medical University, Odesa, Ukraine. E-mail: crocus_aesthetic@my.com, ORCID 0000-0001-8420-5617.

Voloshchuk H. Yu. - Assistant of the Department of Organization and Economics of Pharmacy, Odesa National Medical University, Odesa, Ukraine. E-mail: volosh20@ukr.net, ORCID 0000-0002-9267-3573.

Berbat T. I. - PhD (Chemistry), Assistant of the Department of Organization and Economics of Pharmacy, Odesa National Medical University, Odesa, Ukraine. E-mail: berbat@ukr.net, ORCID 0000-0003-0788-5799.

Yamilova T. M. - PhD (Medicine), Associate Professor of the Department of Professional Pathology and Functional Diagnostics, Odesa National Medical University, Odesa, Ukraine. E-mail: juravuhk@gmail.com, ORCID 0000-0001-9609-1688 Stepanova O. A. - Senior Lecturer of the Department of Organization and Economics of Pharmacy, Odesa National Medical University, Odesa, Ukraine. E-mail: stepanova74@ukr.net, ORCID 0000-0003-3218-2702. 